\title{
ВИКОРИСТАННЯ НЕТРАДИЦЙНИХ МЕТОДІВ ОЗДОРОВЛЕННЯ СТУДЕНТІВ СПЕЦІАЛЬНОЇ МЕДИЧНОЇ ГРУПИ НА ЗАНЯТТЯХ ФІЗИЧНОЇ КУЛЬТУРИ В КОМУНАЛЬНОМУ ЗАКЛАДІ «ОДЕСЬКИЙ ОБЛАСНИЙ БАЗОВИЙ МЕДИЧНИЙ ФАХОВИЙ КОЛЕДЖ»
}

\author{
Н. І. Тарасенко, С. В. Юркул
}

Комунальний заклад «Одеський обласний базовий медичний фаховий коледж»

\begin{abstract}
Зі статистичних даних відомо, що кількість студентів, які входять за станом здоров’я до спеціальної медичної групи, протягом останніх років значно зросла. Тому нами у вигляді експерименту застосовано програми 3 використанням нетрадиційних оздоровчих методик дихальної гімнастики за А. Н. Стрельниковою і звукової гімнастики для оздоровлення студентів зі захворюваннями органів дихання. У результаті дослідження спостерігали чітко виражену тенденцію до збільшення показників функціонального стану кардіореспіраторної системи, підвищення резистентності, працездатності організму та інтересу студентів до занять фізичною культурою в спеціальній медичній групі.
\end{abstract}

\section{IMPLEMENTATION OF ALTERNATIVE HEALING METHODS FOR STUDENTS OF SPECIAL MEDICAL GROUP DURING PHYSICAL TRAINING LESSONS IN ODESA REGIONAL PRIMARY MEDICAL PROFESSIONAL COLLEGE}

\author{
N. I. Tarasenko, S. V. Yurkul \\ Odesa Regional Primary Medical Professional College
}

\begin{abstract}
Statistical data show that the number of students, included to special medical groups (SMGs) has increased significantly in recent years. Therefore, we used programs of alternative healing methods with the implementation of breathing exercises by A. N. Strelnikova and sound gymnastic for the recovery of students with respiratory disorders. As a result of the study the students demonstrated a clear trend to the improvement of functional status of cardiovascular and respiratory systems.
\end{abstract}

Вступ. Відповідно до нормативних документів, фізичне виховання у вищих закладах освіти спрямовано на збереження й зміцнення здоров'я студентів, забезпечення фізичної готовності до життєдіяльності та високопродуктивної праці. Останнім часом у країні разом із погіршенням стану здоров'я спостерігають і зниження рівня фізичної підготовленості студентів. Унаслідок цього ведуть пошук нових шляхів поліпшення здоров'я і фізичної підготовленості студентів через заняття фізичною культурою у закладах вищої освіти.

Вагоме значення в житті людини має фізична культура, що надає їй найрізноманітніші засоби для зміцнення здоров'я, у тому числі з лікувально-профілактичною метою. Головне у фізичній культурі - вправи, або спеціально підібрані комплекси м'язових рухів, що застосовують для загального зміцнення організму,

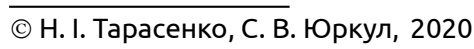

фізичного розвитку, вироблення потрібних у житті навичок. Крім фізичних якостей (швидкість, сила, витривалість, спритність), завдяки фізичній культурі розвиваються ціннісні психічні якості - наполегливість, воля, цілеспрямованість, рішучість, самовладання.

Здоров'я дітей і підлітків багато в чому залежить від рівня рухової активності, фізичних здібностей, функціонування окремих систем і всього організму, а також особливостей їхнього морфофункціонального розвитку в різні вікові періоди.

В останні роки серед молоді України спостерігають несприятливу ситуацію, пов'язану зі зростанням числа захворювань (на 26,8 \% більше, ніж 10 років тому), зниженням рівня фізичного розвитку та фізичної підготовленості студентів. Основними причинами такого положення $\epsilon$ негативні фактори соціально-економічного і екологічного характеру $[1,11]$.

40 ISSN 2411-1597. МЕДСЕСТРИНСТВО. 2020. № 3 
Протягом останніх 5-7 років навчальні заклади України закінчують усього 3-5 \% підлітків без патології у стані здоров'я. Фахівці подібний факт пов'язують 3 особливостями навчання в установах ВН3. Третина студентів, які зараховані на І курс, страждає на хронічні захворювання [1, 7, 12].

Статистичні дані свідчать про те, що кількість студентів, які входять за станом здоров'я до спеціальних медичних груп, протягом останніх років значно зросла. Так, 30 \% студентів I курсу і 63 \% студентів старших курсів мають різні хронічні захворювання, з них у 31,7 \% виявлено хвороби органів дихання. У зв'язку із цим, оздоровчо-реабілітаційна функція фізичного виховання студентів набуває особливого значення. До числа заходів, спрямованих на зниження рівня захворюваності, варто внести підвищення фізичного розвитку та фізичної підготовленості студентів із патологією органів дихання: розвиток рухової активності, застосування сучасних оздоровчих педагогічних технологій, що забезпечують розкриття функціональних можливостей і профілактику захворювань студентів $[1,6,7]$. Питання профілактики захворювань дихальної системи засобами фізичної культури розглядали багато авторів [4, 6, 9, 10, 13]. Разом із тим, методика профілактики захворювань органів дихання засобами фізичної культури на сьогодні для студентів недостатньо розроблена. Враховуючи чутливість організму підлітків до впливу зовнішнього середовища і особливо високу метеолабільність хворих підлітків, їхню низьку здатність до адаптації в умовах проживання, виникає необхідність цілеспрямованого впливу на функціональні можливості організму шляхом використання нетрадиційних методів оздоровлення на заняттях фізичної культури. Це дозволило нам пропонувати заходи щодо використання нетрадиційних методів оздоровлення підлітків спеціальних медичних груп (СМГ) на заняттях фізичної культури для підвищення функціональних можливостей організму.

Мета дослідження: експериментальне обґрунтування та оцінка ефективності впливу занять фізичної культури (з використанням звукової гімнастики, парадоксальної гімнастики) на фізичну підготовленість студентів спеціальної медичної групи зі захворюваннями органів дихання.

Основна частина. Дослідження проводили протягом навчального року.

Здійснювали аналіз і узагальнення науково-методичної літератури, формулювали мету і завдання дослідження, розробили комплекс звукової гімнас- тики та щоденник самоконтролю для студентів СМГ, а також лікувально-оздоровчу програму з фізичної культури для студентів, які входять за станом здоров'я до спеціальної медичної групи, зі захворюваннями органів дихання. Програма націлена на поліпшення фізичного розвитку, розширення діапазону функціональних можливостей основних систем організму, відновлення та підвищення захисних сил організму і його опірності до різних несприятливих факторів. Заняття фізичною культурою в СМГ зі студентами, які мають патологію дихальної системи, проводять шляхом використання в їх в основній і заключній частинах загальновідомої методики парадоксальної дихальної гімнастики за А. Н. Стрельниковою (1989) і звукової гімнастики, яка складається з вправ, що полягають у вимові звуків і їх сполучень строго певним способом. При вимові звуків вібрація голосових складок передається на дихальні шляхи, легені, грудну клітку. Така вібрація дозволяє розслабити спазмовані бронхи і бронхіоли. У експерименті ми враховували той факт, що сила вібрації залежить від сили повітряного струменя, що виникає в процесі вимови тих або інших звуків. 3 огляду на це, всі згідні, що звуки поділяються на 3 групи.

1. Найбільша сила потрібна при вимові глухих приголосних - п, т, к, ф, с; відповідно виникає найбільше напруження м'язів грудної клітки і діафрагми.

2. Середня за силою напруження розвивається в процесі вимови дзвінких приголосних - б, д, г, В, 3.

3. Найменша сила повітряного струменя розвивається у вимові так званих сонат - м, н, л, р.

Також деякі приголосні у звуковій гімнастиці позначаються в такий спосіб: що дзижчать - ж, з; свистячі та шиплячі - с, ф, ц, ш; що гарчать - р. Для вимови різних приголосних звуків потрібна різна сила повітряного струменя, що необхідна для тренування дихальних м'язів. Тому, залежно від типу захворювання дихальної системи, ми стежили за суворим диференціюванням тональності вимови звукових вправ (при бронхіальній астмі та астматичному бронхіті букви, що дзижчать, гарчать, шиплячі звуки вимовляють голосно, енергійно, а при хронічному обструктивному бронхіті - ті ж звуки вимовляють тихо, м'яко). Співвідношення часу на заняттях фізичної культури: 50 \% - на навчання руховим умінням і навичкам, 50 \% - на виконання запропонованих дихальних технік. Заняття проводили 3 рази на тиждень тривалістю 45 хв. Запропонована нами програма для студентів супроводжувалася моніторингом функціональних можливостей системи дихання і кровообігу. 
Здійснювали обробку результатів дослідження.

На початку педагогічного експерименту виявлено, що рівень фізичного розвитку і функціональних можливостей студентів експериментальної та контрольної груп у цілому не мав достовірних розбіжностей (табл. 1). Режим студентів в експериментальній і контрольній групах не відрізнявся. Мали місце різні форми проведення занять фізкультурою в СМГ: у контрольній групі проводили заняття за загальноприйнятою програмою фізичної культури зі зниженням показників, нормативів і відтермінуванням їх складання; в експериментальній групі - комплекси дихальної гімнастики за А. Н. Стрельниковою і звукової гімнастики. Для оцінки ефективності впливу занять фізичного виховання (з використанням звукової гімнастики, парадоксальної гімнастики) на фізичну підготовленість студентів спеціальної медичної групи зі захворюваннями органів дихання використовували такі функціональні дослідження $[2,3,5,12]$. Проби зі затримкою дихання використовували для оцінки функціонального стану дихальної системи, визначення стійкості організму до гіпоксії. Проба Штанге складається з реєстрації тривалості затримки дихання після максимального вдиху. Проба Генчі складається 3 реєстрації тривалості затримки дихання після максимального видиху. Тест Руф'є проводили в положенні сидячи, після 5-хвилинного відпочинку виміряли частоту серцевих скорочень (ЧСС) студента за 15 с (чСС1). Потім він виконує 30 глибоких присідань, викидаючи руки вперед, за 45 с і відразу ж сідає на стілець. Підраховують ЧСС відразу за перші 15 с після навантаження (ЧСС2), потім в останні 15 с першої хвилини після навантаження (ЧССЗ). Індекс Руф'є розраховували за формулою:

$$
\text { Індекс Ру } \phi^{\prime} \epsilon=\frac{4 \cdot(4 С C 1+4 С C 2+4 С С 3)-200}{10}
$$

Екскурсію грудної клітки визначали шляхом виміру окружності грудної клітки на висоті вдиху та видиху. Життєва ємність легень (ЖЕЛ) - показник зовнішнього дихання, який являє собою обсяг повітря, що виходить із дихальних шляхів при максимальному видиху, зробленому після максимального вдиху. На завершальному етапі дослідження студентів експериментальної та контрольної груп показники стану кардіореспіраторної системи були помітно змінені убік прогресу в експериментальній групі (табл. 1).

Таблиця 1. Соматометричні та фізіометричні показники студентів до і після дослідження

\begin{tabular}{|c|c|c|c|c|c|c|c|c|}
\hline \multirow{3}{*}{ Показники } & \multicolumn{4}{|c|}{ До дослідження } & \multicolumn{4}{|c|}{ Після дослідження } \\
\hline & \multicolumn{2}{|c|}{ експериментальна група } & \multicolumn{2}{|c|}{ контрольна група } & \multicolumn{2}{|c|}{ експериментальна група } & \multicolumn{2}{|c|}{ контрольна група } \\
\hline & юнаки & дівчата & юнаки & дівчата & юнаки & дівчата & юнаки & дівчата \\
\hline $\begin{array}{l}\text { Екскурсія } \\
\text { грудної клітки, } \\
\text { см }\end{array}$ & $5,71 \pm 0,83$ & $4,38 \pm 0,96$ & $6,46 \pm 0,88$ & $4,75 \pm 0,93$ & $8,71 \pm 0,61$ & $7,85 \pm 0,55$ & $6,62 \pm 0,65$ & $6,5 \pm 1,10$ \\
\hline \begin{tabular}{l|} 
Життєва \\
ємність \\
легень, \\
мл \\
\end{tabular} & $\begin{array}{c}1618,57 \pm \\
61,25\end{array}$ & $\begin{array}{c}1567,69 \pm \\
36,41\end{array}$ & $\begin{array}{c}1686,15 \pm \\
36,41\end{array}$ & $\begin{array}{c}1635,63 \pm \\
51,38\end{array}$ & $\begin{array}{c}1854,29 \pm \\
64,65\end{array}$ & $\begin{array}{c}1721,54 \pm \\
75,26\end{array}$ & $\begin{array}{c}1732,3 \pm \\
70,02\end{array}$ & $\begin{array}{c}1666,88 \pm \\
50,56\end{array}$ \\
\hline $\begin{array}{l}\text { Проба } \\
\text { Штанге, с }\end{array}$ & $24,07 \pm 1,73$ & $19,92 \pm 1,32$ & $23,69 \pm 1,44$ & $20,81 \pm 1,42$ & $33,29 \pm 2,37$ & $29,92 \pm 1,32$ & $25,541,61 \pm$ & $23,13 \pm 1,67$ \\
\hline $\begin{array}{l}\text { Проба } \\
\text { Генчі, с }\end{array}$ & $10,14 \pm 1,17$ & $8,62 \pm 1,12$ & $9,92 \pm 0,76$ & $9,69 \pm 0,70$ & $12,57 \pm 0,94$ & $10,85 \pm 0,69$ & $10,08 \pm 0,64$ & $9,94 \pm 0,57$ \\
\hline $\begin{array}{l}\text { Пульс у спокої, } \\
\text { уд./хв }\end{array}$ & $87,71 \pm 1,38$ & $89,23 \pm 1,48$ & $88,54 \pm 1,13$ & $88,56 \pm 0,96$ & $78,57 \pm 2,90$ & $79,77 \pm 1,92$ & $83,38 \pm 1,71$ & $86,06 \pm 2,38$ \\
\hline $\begin{array}{l}\text { Індекс } \\
\text { Pу } \phi^{\prime} \epsilon\end{array}$ & $12,64 \pm 0,93$ & $11,00 \pm 0,58$ & $11,92 \pm 0,95$ & $11,81 \pm 0,75$ & $4,93 \pm 0,73$ & $7,31 \pm 0,95$ & $10,08 \pm 0,64$ & $11,44 \pm 1,03$ \\
\hline & & & & $p=0,05$ & & & & \\
\hline
\end{tabular}

Це насамперед стосувалося Ж ЖЛ: у юнаків цей показник збільшився від $(1618,57 \pm 61,25)$ до $(1854,29 \pm 64,65)$ мл, тобто на $11,5 \%$; у дівчат - від $(1567,69 \pm 74,40)$ до $(1721,54 \pm 75,26)$ мл, тобто на $11 \%$. Екскурсія грудної клітки у юнаків збільшилася від $(5,71 \pm 0,83)$ до $(8,71 \pm 0,61)$ см (на 15,25 \%), у дівчат - від $(4,38 \pm 0,96)$ до $(7,85 \pm 0,55)$ см (на 17,92 \%). Показники проби Штанге збільшилися у юнаків від $(24,07 \pm 1,73)$ до $(33,29 \pm 2,37)$ с, тобто на $13,8 \%$, а у дівчат - від $(19,92 \pm 1,32)$ до $(29,92 \pm 1,32)$ с, тобто на $15 \%$; проба Генчі збільшилася у юнаків від $(10,14 \pm 1,17)$ до $(12,57 \pm 0,94)$ с, тобто на $12,4 \%$; у дівчат - від $(8,62 \pm 1,12)$ до $(10,85 \pm 0,69)$ с, тобто на $12,6 \%$. Кількість частоти серцевих скорочень зменшилася у юнаків від $(87,71 \pm 1,38)$ до $(78,57 \pm 2,90)$ уд./Хв, тобто на $11,16 \%$; у дівчат - від $(89,23 \pm 1,48)$ до $(79,77 \pm 1,92)$ уд./хв, тоб- 
то на 11,18 \%. Індекс Руф'є поліпшився на 25,63 \% у юнаків і на 15,04 \% - у дівчат. На відміну від експериментальної групи, показники контрольної групи були змінені несуттєво: екскурсія грудної клітки у юнаків від $(6,46 \pm 0,88)$ до $(6,62 \pm 0,65)$ см (на $1,02 \%)$, у дівчат - від $(4,75 \pm 0,93)$ до $(5,50 \pm 1,10)$ см (на $1,15 \%)$. жєЛ у юнаків від $(1686,15 \pm 36,41)$ до $(1732,31 \pm 70,02)$ мл (на 1,02 \%), у дівчат - від $(1635,63 \pm 51,38)$ до $(1666,88 \pm 50,56)$ мл (на 1,02 \%). Проба Штанге у юнаків від $(23,69 \pm 1,44)$ до $(25,54 \pm 1,61)$ с (на $1,08 \%)$, у дівчат - від $(20,81 \pm 1,42)$ до $(23,13 \pm 1,67)$ с (на $1,11 \%)$. Проба Генчі у юнаків збільшилася від $(9,92 \pm 0,76)$ до $(10,08 \pm 0,64)$ с (на 1,01 \%), у дівчат - від $(9,69 \pm 0,70)$ до $(9,94 \pm 0,57)$ с (на $1,03 \%)$. Частота серцевих скорочень зменшилася у юнаків від $(88,54 \pm 1,13)$ до $(83,38 \pm 1,71)$ уд./хв (на $2,63 \%)$, у дівчат - від $(88,56 \pm 0,96)$ до $(86,06 \pm 2,38)$ уд./хв (на 1,03 \%). Індекс Руф'є поліпшився у юнаків на 1,18 \%, у дівчат на $1,03 \%$.

Необхідно зазначити, що за період дослідження кількість загострень і простудних захворювань в експериментальній групі на $21 \%$ менша, ніж у контрольній групі. Відзначено тенденцію до підвищення працездатності та інтересу студентів до занять фізичної культури із «нестандартним» змістом заняття і бажанням займатися додатково, поліпшення емо-

\section{СПИСОК ЛІТЕРАТУРИ}

1. Айстраханов Д. Д. Загальний огляд медико-демографічної ситуації та аналіз тенденції у сфері охорони здоров'я за останні п'ять років (2002-2006 рр.) / Д. Д. Айстраханов, М. В. Банчук // Україна. Здоров'я нації. - 2007. - № 3-4. - С. 7-15.

2. Апанасенко Г. Л. Физическое развитие детей и подростков / Г. Л. Апанасенко. - К. : Здоровье, 2005. - 96 с.

3. Апанасенко Г. Л. Медицинская валеология / Г. Л. Апанасенко, Л. А. Попова. - К. : Здоровье, 2000. $244 \mathrm{c}$.

4. Булич Э. Г. Физическое воспитание в специальных медицинских группах / Э. Г. Булич. - М. : Высшая школа, 2001. - 756 c.

5. Детская спортивная медицина / [под ред. А. Тихвинского]. - М. : Медицина, 2003. - 549 с.

6. Ефимов А. Применение оздоровительных дыхательных упражнений на уроках физического воспитания детей младшего школьного возраста / А. Ефимов, И. Берестецкая, С. Костикова // Человек в мире спорта. Новые идеи, технологии, перспективы : материалы Международного конгресса. - М., 2002. - Т. 1. - С. 307-308.

7. Гігієнічна оцінка використання здоров'яформуючого потенціалу навчальних закладів / І. О. Калиниченко, ційного стану студентів в експериментальній групі. А також використання спеціальних дихальних технік викликає інтерес у викладачів, тому що виконання вправ не вимагає спеціального забезпечення і витрат.

Висновки. 1. Аналізуючи результати проведеного дослідження і статистичних даних захворюваності дихальної системи серед студентів в Україні, виникає гостра необхідність використання різноманітних оздоровчо-реабілітаційних програм, спрямованих на зміцнення здоров'я підлітків.

2. У результаті застосування у вигляді експерименту програм із використанням оздоровчих методик дихальної гімнастики за А. Н. Стрельниковою і звукової гімнастики для оздоровлення підлітків зі захворюванням органів дихання чітко простежується тенденція до збільшення показників функціонального стану кардіореспіраторної системи, підвищення резистентності працездатності організму та інтересу до занять фізичною культурою в СМГ.

3. Отримані дані відносно валеомоніторингу фізичного стану здоров'я студентів, які часто хворіють, доводять необхідність використання в навчальних закладах реабілітаційно-оздоровчих заходів у системі їхнього фізичного виховання.

Н. С. Полька, Л. М. Заїка, О. Я. Толокольников // Довкілля та здоров'я. - 2008. - № 3 (46). - С. 53-58.

8. Кузнецова Т. Д. Дыхательные упражнения в физическом воспитании / Т. Д. Кузнецова, П. М. Левитский, В. С. Язловецкий. - К. : Здоровье, 2002. - 136 с.

9. Милюкова И. В. Полная энциклопедия лечебной гимнастики / И. В. Милюкова, Т. А. Евдокимова ; под общей ред. Т. А. Евдокимовой]. - СПб. : Сова, 2003. - 512 с.

10. Рипа М. Д. Занятия физической культурой со школьниками, отнесёнными к специальной медицинской группе / М. Д. Рипа, В. К. Велитченко, С. С. Волкова. - М. : Медицина, 2008. - 175 с.

11. Самойлович В. А. Сучасні медико-біологічні засоби реабілітації в валеології : навч. посіб. / В. А. Самойлович, Н. І. Кушакова. - Слов'янськ, 2007. - 208 с.

12. Самойлович В. А. Методичні рекомендації до навчальних занять з фізичної культури в спеціальній медичній групі / В. А. Самойлович, Ю. Ю. Мусхаріна. Слов'янськ : СДПУ, 2008. - 38 с.

13. Язловецкий В. С. Физическое воспитание подростков с ослабленным здоровьем / В. С. Язловецкий. - К. : Здоровье, 2004. -136 с. 